REGARDS

SUR LECONOMIE ALLEMANDE

BULLETIN ECONOMIQUE DU CIRAC

\section{Regards sur l'économie allemande}

Bulletin économique du CIRAC

69 | 2004

Varia

\title{
Services publics
}

KILLIAN Werner, SCHNEIDER Karsten, Umgestaltung des öffentlichen Sektors. Analyse und Handlungsempfehlungen

\section{CpenEdition}

Journals

Édition électronique

URL : http://journals.openedition.org/rea/3533

DOI : $10.4000 /$ rea.3533

ISBN : 978-2-8218-0834-8

ISSN : 1965-0787

Éditeur

CIRAC

Édition imprimée

Date de publication : 1 décembre 2004

ISSN : 1156-8992

Référence électronique

"Services publics », Regards sur l'économie allemande [En ligne], 69 | décembre 2004, mis en ligne le 27 janvier 2009, consulté le 22 septembre 2020. URL : http://journals.openedition.org/rea/3533 ; DOI https://doi.org/10.4000/rea.3533

Ce document a été généré automatiquement le 22 septembre 2020

(C) CIRAC 


\section{Services publics}

KILLIAN Werner, SCHNEIDER Karsten, Umgestaltung des öffentlichen

Sektors. Analyse und Handlungsempfehlungen

\section{RÉFÉRENCE}

KILLIAN Werner, SCHNEIDER Karsten, Umgestaltung des öffentlichen Sektors.

Analyse und Handlungsempfehlungen, Coll. Betriebs- und Dienstvereinbarungen de la Fondation Hans Böckler, Bund Verlag, Francfort-M., 2003, 112 p.

1 La libéralisation des services publics, en brouillant les contours de ce qui fut le „secteur public", a transformé la base sur laquelle étaient établies les conventions de branche. La régulation s'effectue aujourd'hui principalement au niveau de l'entreprise, donnant lieu à des accords d'entreprise. Le présent ouvrage, destiné aux membres des conseils d'établissement et aux syndicalistes, passe en revue les 86 accords conclus entre 1993 et 2002, principalement dans l'administration communale. (ib) 